\title{
ANALISIS PERUBAHAN LABA KOTOR PADA UD SOFY DI SAMARINDA
}

\author{
Agustina Sipi \\ Elfreda Aplonia Lau \\ Rina Masithoh H
}

\author{
University of 17 Agustus 1945 Samarinda \\ J1. Ir. H. Juanda No. 80, 75124, Indonesia \\ elfredalau9@gmail.com
}

\begin{abstract}
This study aims to analyze diverse of gross profit in UD Sofy Samarinda from the results of cement tonasa sales in 2016 compared to 2015. In addition, this study aims to investigate the factors that cause change in gross profit from the sales aspect as well as from the aspect of cost of goods sold

The theory used in this study is management accounting theory, especially about gross profit, sales, cost of goods sold, with the first hypothesis that the increase in sales and increase in cost of goods sold causes an increase in gross profit. The second hypothesis of this study is the factors that cause the change in gross profit due to changes in quantity and selling prices, changes in volume (quantity) and the cost of the product unity.

The data collection technique used is library research. The analytical method used is an analysis gross profit change focused on sales price variance analysis, sales volume variance analysis, cost price variance analysis and cost volume variance analysis.

The results of the study pointed that the increase in sales and the increase in cost of goods sold in 2016 caused an increase in the gross profit of cement sales in UD Sofy Samarinda in that year compared to 2016. The results also showed that changes in gross profit (increase in gross profit) were caused by sales price variance, sales volume variance, cost price variance, volume price variance.
\end{abstract}

Keywords: Gross Profit, Sales, Cost of Goods Sold

\section{PENDAHULUAN}

Setiap perusahaan yang

didirikan tentunya hendak terus tumbuh dan berkembang dari waktu ke waktu. Perkembangan dan pertumbuhan ini dapat dilihat dari hasil akhir seluruh kegiatan perusahaan dalam satu periode, dimana periode usaha lazimnya dinyatakan dalam satuan tahun.

Hasil akhir seluruh kegiatan perusahaan tercermin dari laporan keuangannya. Laporan yang mencerminkan perusahaan mengalami kerugian atau memperoleh keuntungan dapat dilihat pada laporan Laba-Rugi. Informasi yang diperoleh dari laporan 
laba rugi selanjutnya dapat dijadikan dasar pengambilan keputusan untuk masa yang akan datang.

Perusahaan tentunya tidak hanya sekedar menerima berapa pendapatan yang diperoleh maupun jumlah pengeluaran yang terjadi serta angka laba maupun angka rugi yang terjadi, melainkan penting bagi perusahaan dalam menganalisis perubahan laba yang terjadi. Perubahan laba yang dimaksudkan dalam penelitian ini adalah perubahan laba kotor.

Penekanan penelitian ini pada analisis perubahan laba kotor didasarkan pada pertimbangan bahwa dengan menganalisis perubahan dalam laba kotor (gross profit) dapat diketahui penyebab perubahan tersebut. Penyebab perubahan laba kotor dapat saja menguntungkan(kenaikan) maupun perubahan yang tidak menguntungkan(penurunan).

Berdasarkan hasil analisis penyebab perubahan laba kotor dapat diambil kesimpulan dan atau diambil tindakan seperlunya untuk periode-periode berikutnya.

Laba kotor diperoleh dari Penjualan Netto dikurangi dengan Harga Pokok Penjualan. Hal ini menunjukkan bahwa perubahan laba kotor disebabkan oleh dua faktor yaitu faktor penjualan dan faktor harga pokok penjualan. Besar kecilnya hasil penjualan dipengaruhi oleh kuantitas penjualan atau volume produk yang dapat dijual dan harga jual persatuan produk tersebut.Oleh karena itu perubahan laba kotor karena adanya perubahan hasil penjualan dapat disebabkan adanya perubahan harga jual per satuan produk dan perubahan kuantitas atau volume produk yang dijual/dihasilkan.

Faktor harga pokok penjualan dipengaruhi oleh kuantitas produk yang dijual dan harga pokok per satuan(ratarata) produk yang dijual/yang dihasilkan tersebut, maka perubahan laba kotor yang disebabkan oleh adanya perubahan harga pokok penjualan dapat disebabkan oleh: perubahan harga pokok rata-rata per satuan dan perubahan kuantitas atau volume produk yang dijual.

Berdasarkan dua faktor penyebab utama terjadinya perubahan laba kotor ditelususuri apa sebabnya penjualan

berubah(naik/turun)perubahan tersebut disebabkan oleh perubahan kuantitas atau perubahan harga jual. Demikian 
pula dapat ditelusuri mengapa terjadinya peruabahan harga pokok penjualan(naik/turun) dan besarnya perubahan yang disebabkan oleh kuantitas atau satuan produk yang terjual maupun besaran harga pokok penjualan yang disebabkan oleh berubahanya biaya atau harga pokok persatuan(unit cost)

Selanjutnya analisis perubahan laba kotor ini dilakukan pada penjualan semen tonasa UD. Sofy. Hal ini didasarkan pada pertimbangan bahwa penjualan semen tonasa pada tahun 2016 mengalami kenaikan dibandingkan dengan penjualan yang terjadi pada tahun 2015.Demikian pula terjadi kenaikan harga pokok. Apakah kenaikan penjualan dan kenaikan harga pokok berdampak menaikkan atau menurunkan Laba Kotor serta unsurunsur apa saja dari harga jual maupun harga pokok yang berpengaruh terhadap laba kotor perlu diteliti lebih lanjut.

\section{KERANGKA TEORITIS}

Teori yang digunakan dalam penelitian ini adalah akuntansi manajemen. Para pakar mendefinisikan akuntansi manajemen sebagai berikut: Darsono (2008:3) mendefinisikan akuntansi manajemen sebagai serangkaian tindakan dan proses akuntansi yang bertujuan untuk mengukur dan mengevaluasi kinerja personal yang terlibat dalam organisasi dengan menggunakan ukuran kinerja keuangan. Selain itu akuntansi manajemen juga berguna untuk membuat strategi dan rencana jangka panjang. Lebih lanjut Rudianto (2013:9) berpendapat bahwa akuntansi manajemen adalah sistem akuntansi, yakni jenis informasi yang dihasilkan ditujukan kepada pihak-pihak internal organisasi, seperti manajer keuangan, manajer produksi, manajer pemasaran dan sebagainya guna pengambilan keputusan internal organisasi. Kemudian Horngren (2008:2) berpendapat bahwa akuntansi manajemen mengukur, menganalisis dan melaporkan informasi keuangan dan non keuangan yang membantu manajer membuat keptusan guna mencapai tujuan organisasi. Manajer akan menggunakan informasi akuntansi manajemen ini untuk memilih, mengkomunikasikan dan mengimplementasikan strategi.

Merurut Mulyadi (2007:3) akuntansi manajemen adalah suatu informasi keuangan yang dihasilkan oleh tipe akuntansi manajemen yang digunakan terutama oleh pengguna 
intern suatu organisasi. Menurut Halim dan Supomo (2007:4) akuntansi manajemen merupakan Kegiatan atau proses yang menghasilakn informasi dalam bentuk keuangan bagi manajemen untuk pengambilan sebuah keputusan ekonomi dalam menjalankan fungsi manajemen.

Menurut Supriyono (2007:8) mengutip dari accounting practices (MPA) komite yang dibentuk oleh National Association of Accountants (NAA) bahwa akuntansi manajemen ialah Suatu proses identifikasi, pengukuran, pengumpulan data, analisis, penyiapan, dan komunikasi informasi financial yang digunakan manajemen untuk sebuah perencanaa, evaluasi, pengendalian, dalam suatu organisasi atau perusahaan, serta menjamin ketepatan penggunaan sumber dan pertanggung jawaban atas segala sumber tersebut.Menurut Hansen dan Mowen (2007: 9) akuntansi manajemen merupakan alat untuk mengidentifikasi, mengumpulkan, mengukur, mengklasifikasi, dan melaporkan informasi yang bermanfaat bagi pengguna internal dalam merencanakan, mengendalikan, dan mengambil keputusan. Hal ini sejalan dengan pendapat Siregar, dkk (2013:1) yang mendefinisikan akuntansi manajemen sebagai berikut:Akuntansi manajemen (management accounting) adalah proses mengidentifikasi, mengukur, mengakumulasi, menyiapkan, menganalisis, menginterpretasikan, dan mengkomunikasikan kejadian ekonomi yang digunakan oleh manajemen untuk melakukan perencanaan, pengendalian, pengambilan keputusan, dan penilaian kinerja dalam organisasi.

\section{Laporan Keuangan}

Menurut Munawir

(2008:2) Laporan keuangan pada dasarnya adalah hasil dari proses akuntansi yang dapat digunakan sebagai alat untuk berkomunikasi antara data keuangan atau aktivitas suatu perusahaan dengan pihak-pihak yang berkepentingan dengan data atau efektivitas perusahaan tersebut.

Menurut Baridwan (2009:17) adalah Laporan keuangan merupakan ringkasan dari suatu proses pencatatan, merupakan suatu ringkasan dari transaksi-transaksi keunangan yang terjadi selama tahun buku yang bersangkutan.

Kasmir

(2012:

mengetengahkan bahwa tujuan pembuatan atau penyususnan laporan 
keuangan yaitu: Memberikan informasi tentang jenis dan jumlah aktiva (harta) yang dimiliki perusahaan pada saat ini. Memberikan informasi tentang jenis dan jumlah kewajiban dan modal yang dimiliki perusahaan pada saat ini. Memberikan informasi tentang jenis dan jumlah pendapatan yang diperoleh pada suatu periode tertentu. Memberikan informasi tentang jumlah biaya dan jenis biaya yang dikeluarkan perusahaan dalam suatu periode tertentu. Memberikan informasi tentang perubahan - perubahan yang terjadi terhadap aktiva, pasiva, dan modal perusahaan. Memberikan informasi tentang kinerja manajemen perusahaan dalam suatu periode. Memberikan informasi tentang catatan - catatan atas laporan keuangan. Informasi keuangan lainnya.

\section{Harga Pokok Penjualan}

Menurut Gill dan Chatton (2008

:15) Harga Pokok Penjualan adalah biaya pembuatan atau harga pembelian yang melekat pada produk barang jadi yang dikirim dari pemasok ke pelanggan. Menurut Rudianto (2012: 116) harga pokok penjualan adalah Harga beli barang - barang yang dijual selama satu periode akuntansi.

\section{Laba}

Laba atau keuntungan salah satu tujuan utama perusahaan dalam menjalankan aktivitasnya. Pihak manajemen selalu merencanakan besar perolehan laba sertiap periode, yang ditentukan melalui target yang harus dicapai.

Menurut Hanafi (2009: 32) laba adalah Ukuran keseluruhan prestasi perusahaan, yang didefinisikan sebagai berikut: Laba $=$ Penjualan - Biaya .

Menurut Harahap (2013: 113) laba adalah Kelebihan penghasilan diatas biaya selama satu periode akuntansi.

\section{Analisa Laba Kotor}

Salah satu alat bantu manajemen perusahaaan yang dapat digunakan adalah analisis laba kotor dimana analisis kotor ini digunakan untuk mengevaluasi penjualan dan menganalisis hasil pelaksanaan atau aktivitas penjualan dalam perusahaan, dengan cara membandingkan antara anggaran laba kotor yang disusun dengan realisasi yang terjadi sehingga dapat diketahui hasil yang diperoleh perusahaan.

Besarnya laba perusahaan dihitung dengan mempertemukan secara layak semua penghasilan dengan semua biaya didalam suatu periode akuntansi yang sama. Keberhasilan manajemen 
dapat dilihat dari apakah laba yang diperoleh lebih besar atau lebih kecil dibandingkan dengan rencana laba yang semula ingin dicapai. Rencana laba dapat berupa laba yang dianggarkan atau standar laba peroide akuntansi sebelumnya.

Menurut Supriyono (2007:175) bahwa penyimpangan realisasi laba dengan rencana laba perlu dianalisis dan diinvestigasi sebab-sebab penyimpangannya, sehingga dapat digunakan sebagai alat untuk tujuan:

a. Memberikan petunjuk kepada manajemen tentang elemen apa yang menyimpang, berapa jumlah penyimpangannya dan bagaimana pengaruhnya terhadap laba yang dicapai perusahaan, apa sebab penyimpangan tersebut, pada kegiatan apa penyimpangan itu terjadi, siapa yang betanggung jawab terhadap penyimpangan tersebut atau apakah penyimpangan tersebut dapat dikendalikan oleh pusat kegiatan tertentu.

b. Memberikan petunjuk kepada manajemen guna menyusun anggaran laba periode berikutnya, dengan investigasi terhadap penyimpangan yang timbul dapat menilai apakah rencana laba merupakan pengukur yang baik untuk menilai/mengevaluasi laba. Apabila rencana laba tidak tepat maka akibatnya tidak dapat dipakai sebagai alat evaluasi dan menentukan rencana laba periode berikutnya harus lebih teliti.

Tujuan menganalisis penyimpangan yang terjadi antara realisasi laba dengan rencana laba. Maka laporan laba rugi perlu dibandingkan antara realisasi laba apakah menguntungkan atau merugikan. Analisis laba kotor merupakan bagian dari analisis laba. Berdasarkan uraian diatas perubahan laba kotor dipengaruhi oleh elemen penjualan dan harga pokok penjualan, maka dari itu perlu dilakukan analisis terhadap perubahan laba kotor.

Menurut Munawir (2012: 137) Analisa perubahan laba kotor (Gross Profit Analysis) adalah suatu analisa untuk mengetahui sebab-sebab perubahan laba kotor suatu perusahaan dari periode ke periode yang lain atau perubahan laba kotor suatu periode dengan laba yang di bugetkan untuk periode tersebut. Dijelaskan pula oleh Munawir (2012: 216) bahwa besar kecilnya hasil penjualan dipengaruhi oleh kualitas atau volume produk yang dapat dijual dan harga jual persatuan 
produk tersebut. Oleh karena itu

(rata-rata) produk yang dijual perubahan laba kotor karena adanya disebabkan oleh adanya perubahan perubahan hasil penjualan dapat disebabkan adanya: perubahan harga jual per satuan produk dan perubahan kuantitas atau volume produk yang dijual atau dihasilkan

Faktor harga pokok penjualan juga dipengaruhi oleh kuantitas produk yang dijual dan harga pokok per satuan harga pokok penjualan dapat disebabkan oleh perubahan harga pokok rata-rata persatuan dan perubahan kuantitas atau volume produk yang dijual.

\section{Kerangka Pikir}

Penelitian ini dilakukan dengan kerangka pikir sebagai berikut:

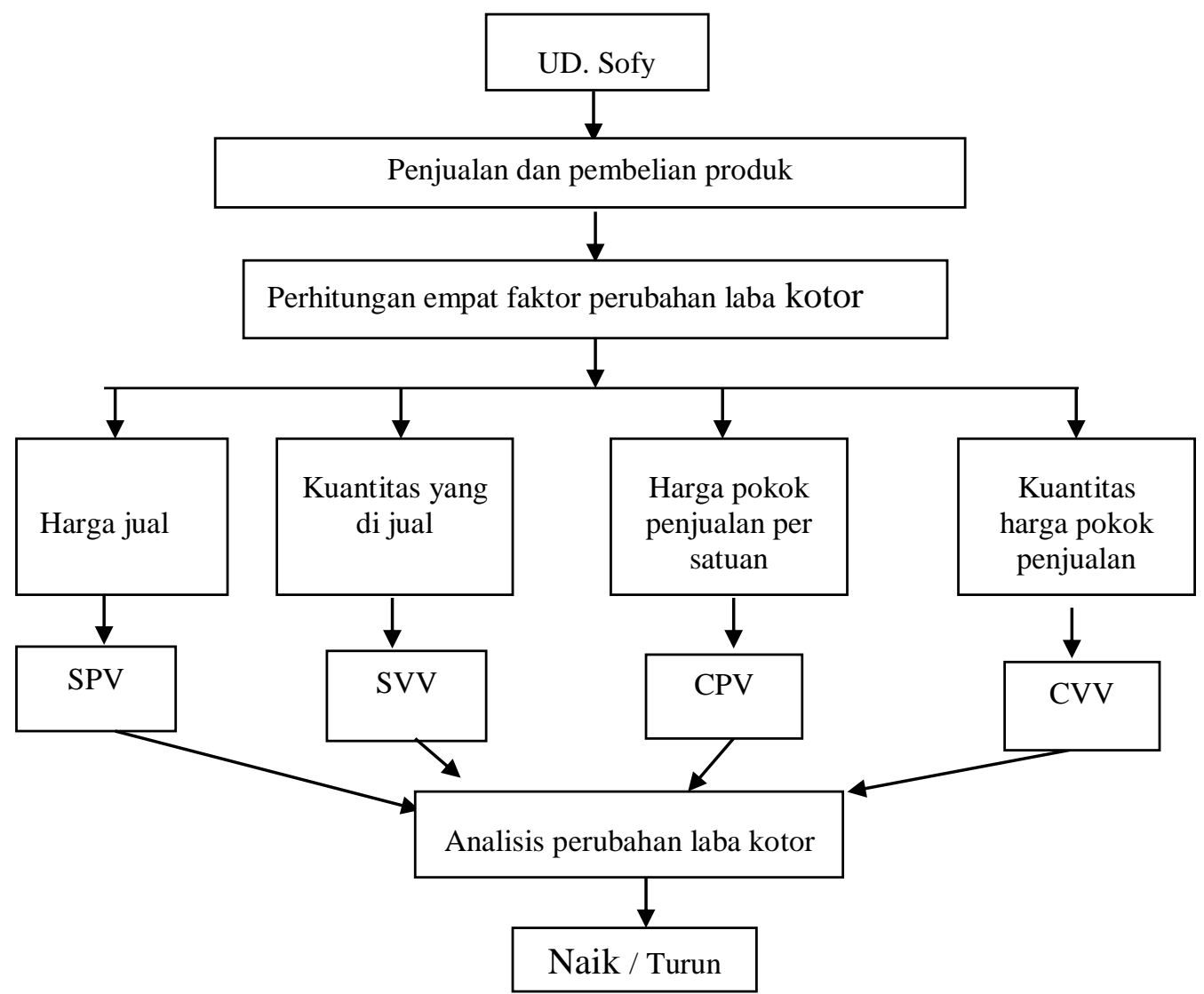

Keterangan:

SPV Perubahan Harga Jual (Sales Price Variance)

SVV Perubahan Kuantitas Produk yang dijual (Sales Volume Variance)

CPV Perubahan Harga Pokok Penjualan Per Satuan Pokok (Cost Price Variance)
CVV Perubahan Kuantitas Harga Pokok Penjualan (Cost Volume Variance)

\section{Hipotesis}

Berdasarkan rumusan masalah dan dasar teori maka hipotesis penelitian ini adalah 
1. Laba kotor penjualan semen UD. Sofy mengalami kenaikan dari tahun 2015 ke tahun 2016

2. Faktor - faktor yang menyebabkan naikya laba kotor yaitu perubahan harga jual, perubahan kuantitas produk yang dijual, perubahan harga pokok per satuan produk, perubahan kuantitas harga pokok penjualan.

\section{METODE PENELITIAN}

\section{Definisi Operasional}

Laba kotor adalah laba yang diperoleh UD. Sofy dari selisih penjualan semen tonasa dengan harga pokok penjualan dan dinyatakan dalam satuan rupiah.

Penjualan adalah sejumlah uang yang diperoleh dari hasil kegiatan UD. Sofy dalam menjual semen dengan harapan akan memperoleh laba dari adanya transaksi tersebut dan dinyatakan dalam rupiah

Harga pokok penjualan adalah sejumlah uang yang dikeluarkan UD Sofy untuk membeli semen tonasa dan dinyatakan dalam satuan ruliah.

Harga Jual adalah harga per zak semen tonasa yang ditentukan UD. Sofy untuk dijual kepada konsumen. Perubahan kuantitas penjualan yaitu perbedaan antara kuantitas semen tonasa tahun 2015 dan tahun 2016 pada UD. Sofy.

\section{Teknik Pengumpulan Data}

Pengumpulan data penelitian ini dengan melakukan studi kepustakaan(Library Research ) yaitu perolehan data-data dengan cara menelaah data dokumentasi pada UD. Sofy

\section{Metode Analisis}

Metode analisis yang digunakan dalam penelitian ini adalah analisis perubahan laba kotor. Menurut Munawir (2008:218-220), analisa perubahan laba kotor meliputi tahapan analisis berikut:

1. Perubahan harga jual (sales price variance)

Perubahan laba kotor yang disebabkan adanya perubahan harga jual dapat ditentukan dengan rumus: $\left(\mathrm{HJ}_{2}-\mathrm{HJ}_{1}\right) \mathrm{K}_{2}$

$\mathrm{Hj}_{1}$ : Harga jual persatuan yang dibudgetkan atau tahun sebelumnya $\mathrm{Hj}_{2}$ : Harga jual persatuan produk yang sesungguhnya

$\mathrm{K}_{2}$ : Kuantitas atau volume produk yang sesungguhnya dijual tahun ini.

2. Perubahan kuantitas produk yang dijual (sales volume variance).

Perubahan laba kotor yang 
disebabkan oleh perubahan kuantitas atau volume produk yang dijual dapat ditemukan dengan rumus:

$\left(\mathrm{K}_{2}-\mathrm{K}_{1}\right) \mathrm{HJ}_{1}$

$\mathrm{K}_{2}$ : kuantitas penjualan yang sesungguhnya direalisasikan tahun ini.

$\mathrm{K}_{1}$ : kuantitas penjualan yang dibudgetkan atau tahun sebelumnya $\mathrm{Hj}_{1}$ : Harga jual satuan produk yang dibudgetkan/tahun sebelumnya sebagai standar.

3. Perubahaan harga pokok penjualan per satuan pokok (cost prince variance).Untuk menentukan besarnya perubahan laba kotor yang disebabkan adanya perubahan harga pokok penjualan persatuan produk dapat ditentukan dengan rumusrumus: $\left(\mathrm{HPP}_{2}-\mathrm{HPP}_{1}\right) \mathrm{K}_{2}$

\section{HASIL PENELITIAN}

Data pembelian dan data penjualan produk semen tonasa pada UD Sofy tahun 2016 dan tahun 2015 disajikan per bulan. Keseluruhan data pembelian dan penjualan semen tonasa
$\mathrm{HPP}_{2} \quad$ : Harga pokok penjualan yang sesungguhnya

$\mathrm{HPP}_{1} \quad$ : Harga pokok penjualan menurut budget atau tahun sebelumnya

$\mathrm{K}_{2} \quad$ : $\quad$ Kuantitas produk yang sesungguhnya di jual

4. Perubahan kuantitas harga pokok penjualan (cost volume variance) dihitung rumus: $\left(\mathrm{K}_{2}-\mathrm{K}_{1}\right) \mathrm{HPP}_{2}$ $\mathrm{K}_{2}$ : Kuantitas produk yang sesungguhnya dijual atau dihasilkan. $\mathrm{K}_{1}$ : Kuantitas produk menurut budget atau tahun sebelumnya.

$\mathrm{HPP}_{1}$ : Harga pokok penjualan persatuan barang menurut budget.

Model analisis perubahan laba kotor menurut Munawir tampak sebagai berikut:

pada UD Sofy tahun 2015 dapat dilihat pada tabel 2, sedangkan Keseluruhan data pembelian dan penjualan semen tonasa pada UD Sofy tahun 2015 dapat dilihat pada tabel 1 .

Tabel 1. Data pembelian dan penjualan semen Tonasa UD. Sofy Tahun 2015

UD. SOFY

\section{Data Pembelian dan Penjualan Semen Tonasa Tahun 2015}

\begin{tabular}{cccccccc} 
No & Bulan & $\begin{array}{c}\text { Jumlah } \\
\text { Pembelian } \\
\text { produk Per } \\
\text { sak }\end{array}$ & $\begin{array}{c}\text { Harga Beli } \\
\text { per Sak } \\
(\mathbf{R p})\end{array}$ & $\begin{array}{c}\text { Jumlah } \\
\text { Produk } \\
\text { Terjual } \\
\text { Per sak }\end{array}$ & $\begin{array}{c}\text { Harga } \\
\text { Jual Per } \\
\text { Sak (Rp) }\end{array}$ & $\begin{array}{c}\text { Total } \\
\text { Pembelian (Rp) }\end{array}$ & $\begin{array}{c}\text { Total } \\
\text { Penjualan (Rp) }\end{array}$ \\
\hline 1 & Januari & 230 & 33.000 & 230 & 53.000 & 7.590 .000 & 12.190 .000
\end{tabular}




\begin{tabular}{cccccccc}
2 & Februari & 211 & 33.000 & 211 & 53.000 & 6.963 .000 & 11.183 .000 \\
\hline 3 & Maret & 310 & 33.000 & 310 & 53.000 & 10.230 .000 & 16.430 .000 \\
\hline 4 & April & 285 & 33.000 & 285 & 53.000 & 9.405 .000 & 15.105 .000 \\
\hline 5 & Mei & 220 & 33.000 & 220 & 53.000 & 7.260 .000 & 11.660 .000 \\
\hline 6 & Juni & 200 & 33.000 & 200 & 53.000 & 6.600 .000 & 10.600 .000 \\
\hline 7 & Juli & 150 & 33.000 & 150 & 53.000 & 4.950 .000 & 7.950 .000 \\
\hline 8 & Agustus & 320 & 33.000 & 320 & 53.000 & 10.560 .000 & 16.960 .000 \\
\hline 9 & September & 295 & 33.000 & 295 & 53.000 & 9.735 .000 & 15.635 .000 \\
\hline 10 & Oktober & 230 & 33.000 & 230 & 53.000 & 7.590 .000 & 12.190 .000 \\
\hline 11 & November & 350 & 33.000 & 350 & 53.000 & 11.550 .000 & 18.550 .000 \\
\hline 12 & Desember & 329 & 33.000 & 329 & 53.000 & 10.857 .000 & 17.437 .000 \\
\hline Jumlah Total & 3.130 & 396.000 & 3.130 & 636.000 & 103.290 .000 & 165.890 .000 \\
\hline
\end{tabular}

Sumber: UD. Sofy 2018

Tabel 2 Data pembelian dan penjualan semen Tonasa UD. Sofy Tahun 2016 Data Pembelian dan Penjualan Semen Tonasa Tahun 2015

UD. SOFY

\begin{tabular}{|c|c|c|c|c|c|c|c|}
\hline No & Bulan & $\begin{array}{c}\text { Jumlah } \\
\text { Pembelian } \\
\text { produk Per } \\
\text { sak }\end{array}$ & $\begin{array}{c}\text { Harga } \\
\text { Beli per } \\
\text { Sak (Rp) }\end{array}$ & $\begin{array}{l}\text { Jumlah } \\
\text { Produk } \\
\text { Terjual } \\
\text { Per sak }\end{array}$ & $\begin{array}{c}\text { Harga Jual } \\
\text { Per Sak } \\
\text { (Rp) }\end{array}$ & $\begin{array}{c}\text { Total } \\
\text { Pembelian } \\
(\mathbf{R p})\end{array}$ & $\begin{array}{c}\text { Total } \\
\text { Penjualan } \\
\text { (Rp) }\end{array}$ \\
\hline 1 & Januari & 253 & 35.500 & 253 & 57.000 & 8.981 .500 & 14.421 .000 \\
\hline 2 & Februari & 324 & 35.500 & 324 & 57.000 & 11.502 .000 & 18.468 .000 \\
\hline 3 & Maret & 350 & 35.500 & 350 & 57.000 & 12.425 .000 & 19.950 .000 \\
\hline 4 & April & 390 & 35.500 & 390 & 57.000 & 13.845 .000 & 22.230 .000 \\
\hline 5 & Mei & 400 & 35.500 & 400 & 57.000 & 14.200 .000 & 22.800 .000 \\
\hline 6 & Juni & 457 & 35.500 & 457 & 57.000 & 16.223 .500 & 26.049 .000 \\
\hline 7 & Juli & 200 & 35.500 & 200 & 57.000 & 7.100 .000 & 11.400 .000 \\
\hline 8 & Agustus & 297 & 35.500 & 297 & 57.000 & 10.543 .500 & 16.929 .000 \\
\hline 9 & September & 315 & 35.500 & 315 & 57.000 & 11.182 .500 & 17.955 .000 \\
\hline 10 & Oktober & 333 & & 333 & 57.000 & & \\
\hline
\end{tabular}




\begin{tabular}{|c|c|c|c|c|c|c|c|}
\hline & \multicolumn{5}{|c|}{35.500} & \multirow{2}{*}{$\begin{array}{l}11.821 .500 \\
11.360 .000\end{array}$} & \multirow{2}{*}{$\begin{array}{r}18.981 .000 \\
18.240 .000 \\
\end{array}$} \\
\hline 11 & November & 320 & 35.500 & 320 & 57.000 & & \\
\hline 12 & Desember & 315 & 35.500 & 315 & 57.000 & 11.182 .500 & 17.955 .000 \\
\hline \multicolumn{2}{|c|}{ Jumlah Total } & 3.954 & 426.000 & 3.954 & 684.000 & 140.367 .000 & 225.378 .000 \\
\hline
\end{tabular}

Sumber: UD. Sofy 2018

\section{ANALISIS DAN PEMBAHASAN}

Data - data yang telah dihimpun dianalisis dengan menggunakan alat analisis perubahan laba kotor, yang diawali dengan penyajian laporan laba-rugi tahun 2016 yang diperbandingkan dengan tahun 2015 berikut ini:

Tabel 3 Laporan Laba-Rugi UD Sofy Tahun 2015 dan Tahun 2016

\begin{tabular}{lccc} 
& UD.SOFY \\
& Laporan Laba-Rugi & \\
& Tahun 2015 Dan 2016 & \\
& $\mathbf{2 0 1 5}$ & $\mathbf{2 0 1 6}$ & Kenaikan \\
\hline Penjualan Netto (Rp) & 165.890 .000 & 225.378 .000 & 59.488 .000 \\
\hline Harga Pokok Penjualan (Rp) & 103.290 .000 & 140.367 .000 & 37.077 .000 \\
\hline Laba Kotor (Rp) & 62.600 .000 & 85.011 .000 & 22.411 .000 \\
\hline Kwantitas yang dijual (zak) & 3.130 & 3.954 & 824 \\
\hline Harga jual per satuan (Rp) & 53.000 & 57.000 & 4.000 \\
\hline Harga pokok per satuan (Rp) & 33.000 & 35.500 & 2.500 \\
\hline Sumber: Data diolah, 2018 & &
\end{tabular}

Sumber: Data diolah, 2018

Data laporan laba-rugi tahun 2016 dibandingkan dengan data tahun 2015 menunjukkan adanya kenaikan dalam penjualan sebesar Rp 59.488.000,- dan kenaikan harga pokok penjualan sebesar Rp 37.077.000,- sehingga terjadi kenaikan laba kotor pada tahun 2016 sebesar Rp 22.411.000. Selanjutnya dilakukan analisis penyebab terjadinya kenaikan laba kotor melalui tahapan berikut ini :

1. Menghitung perubahan laba kotor yang disebabkan oleh faktor penjualan (kuantitas maupun harga jual).

Kenaikan laba kotor karena harga jual $=\left(\mathrm{Hj}_{2}-\mathrm{Hj}_{1}\right) \mathrm{K}_{2}=($ Rp. 57.000 
- Rp. 53.000 ) 3.954 sak $=R p$

15.816.000.

Kenaikan laba kotor karena

kuantitas penjualan $=\left(\mathrm{K}_{2}-\right.$

$\left.\mathrm{K}_{1}\right) \mathrm{Hj}_{1}=(3.954-3.130)$

Rp.53.000 = Rp 43.672.000

2. Menghitung perubahan laba

kotor yang disebabkan oleh

adanya perubahan harga

pokok penjualan per satuan

Berdasarkan hasil perhitungan

faktor-faktor penyebab terjadinya

perubahan laba kotor dari aspek produk maupun kuantitasnya.

Kenaikan laba kotor karena harga pokok penjualan $=\left(\mathrm{HPP}_{2}-\mathrm{HPP}_{1}\right)$ $\mathrm{K}_{2}=($ Rp. $35.500-$ Rp. 33.000$)$ 3.954 sak $=\operatorname{Rp} 9.885 .000$

Kenaikan laba kotor karena kuantitas $\mathrm{HPP}=\left(\mathrm{K}_{2}-\mathrm{K}_{1}\right) \mathrm{HPP}_{1}=(3.954-$ 3.130) Rp. $33.000=\operatorname{Rp} 27.192 .000$.

penjualan maupun dari aspek harga pokok penjualan, disajikan laporan perubahan laba kotor pada tabel 4 .

Tabel 4. Laporan perubahan laba kotor

\section{UD SOFY}

\section{Laporan Perubahan Laba Kotor}

Per 31 Des 2015 dengan 2016

Kenaikan penjualan yang di sebabkan :

Kenaikan harga jual

Kenaikan kuantitas penjualan
Rp. 15.816.000,-

Rp. 43.672.000,- + Rp. 59.488 .000

Kenaikan harga pokok penjualan di sebabkan :

Kenaikan harga pokok persatuan produk $\quad$ Rp. 9.885 .000

Kenaikan kuantitas harga pokok penjualan

Kenaikan laba kotor

Sumber : Data diolah, 2019

Hasil analisis penelusuran faktor-faktor penyebab terjadinya kenaikan penjualan disebabkan oleh tiga faktor yaitu kenaikan kuantitas, kenaikan harga jual serta kenaikan kuantitas dan harga jual.

\section{Rp. $27.192 .000+$}

Rp. $37.077 .000-$

Rp. 22.411 .000
Demikian analisis penelusuran faktorfaktor penyebab terjadinya kenaikan harga pokok penjualan disebabkan pula oleh tiga faktor yaitu kenaikan kuantitas, kenaikan harga pokok serta 
kenaikan kuantitas dan kenaikan harga

pokok disajikan pada tabel 5 .

Tabel 6 Laporan Perubahan Dalam Penjualan, Harga Pokok Penjulan Dan Laba Kotor

\begin{tabular}{llll} 
& \multicolumn{2}{c}{$\begin{array}{c}\text { UD. SOFY } \\
\text { Laporan perubahan dalam Penjualan, } \\
\text { harga Pokok Penjualan Dan Laba Kotor } \\
\text { Akhir Tahun 2016 Dengan 2015 }\end{array}$} & \\
\hline & Penjualan & $\begin{array}{c}\text { Harga Pokok } \\
\text { Penjualan }\end{array}$ & Laba Kotor \\
\hline Jumlah Tahun 2016 & Rp. 225.378.000.- & Rp. 140.367.000.- & Rp. 85.011.000 \\
\hline Jumlah Tahun 2015 & Rp. 165.890.000.- & Rp. 103.290.000,- & Rp. 62.600.000 \\
\hline Kenaikan & RP. 59.488.000,- & Rp. 37.077.000,- & Rp. 22.411.000 \\
\hline
\end{tabular}

Sumber : Data diolah, 2018

Kenaikan - Penurunan* disebabkan oleh :

Faktor kuantitas $\quad$ Rp. 43.672.000,- $\quad$ Rp. 27.192.000,- Rp. 16.480.000,-

Faktor harga jual Rp. 12.520.000,- $\quad-\quad$ Rp. 12.520.000,-

Faktor harga pokok $\quad-\quad$ Rp. 7.825.000,- Rp. 7.825.000,-*

Faktor kuantitas $\quad$ Rp. 3.296.000,- $\quad-\quad$ Rp. 3.296.000,-

$\&$ harga jual

Faktor kuantitas $\quad-\quad$ Rp. $2.060 .000,-\quad$ Rp. $2.060 .000,-*$

\& harga pokok

Jumlah $\quad \underline{\text { Rp. 59.488.000,- }} \quad$ Rp. 37.077.000,- $\quad$ Rp. 22.411.000,-

\section{Pembahasan}

Hasil analisis menunjukkan bahwa terjadi perubahan laba kotor dari tahun 2015 ke tahun 2016 sebesar Rp. 22.411.000,- perubahan laba kotor tersebut terjadi karena :

1. Faktor kuantitas penjualan mengalami kenaikan sebesar Rp. 43.672.000,-
2. Faktor harga jual mengalami kenaikan sebesar Rp. 12.520.000,-

3. Faktor kuantitas dan harga jual mengalami kenaikan sebesar Rp. 3.296.000,-

4. Faktor harga pokok mengalami kenaikan sebesar Rp.7.825.000,-

5. Faktor volume/kuantitas harga pokok sebesar Rp. 27.192.000,- 
6. Faktor kuantitas dan harga pokok mengalami kenaikan sebesar $\mathrm{Rp}$. 2.060.000,-

Hasil analisis membuktikan bahwa faktor perubahan laba kotor terjadi karena

1. Perubahan harga jual

2. Perubahan kuantitas produk yang di jual

3. Perubahan harga pokok penjualan per satuan produk

4. Perubahan kuantitas harga pokok penjualan

\section{KESIMPULAN DAN SARAN}

\section{Kesimpulan}

Berdasarkan hasil analisis dan pembahasan yang di lakukan maka dapat disimpulkan bahwa :

1. Kenaikan penjualan dan kenaikan harga pokok penjualan semen tonasa UD Sofy dari tahun $2015 \mathrm{ke}$ tahun 2016 menyebabkan kenaikan perubahan laba kotor sehingga hipotesis penelitian ini diterima.

2 Kenaikan laba kotor disebabkan oleh kenaikan harga jual dan kuantitas penjualan, perubahan harga pokok per satuan produk dan perubahan kuantitas harga pokok penjualan maka hipotesis penelitian ini diterima.

\section{Saran}

Berdasarkan hasil analisis maka disarankan bagi

perusahaan hendaknya terus meningkatkan penjualannya agar terjadi kenaikan perubahan laba kotor yang stabil setiap tahunnya.

\section{DAFTAR PUSTAKA}

Baridwan Zaki, 2009, Intermediate Accounting, BPFE, Yogyakarta.

Chatton, Moira dan Gill, James,2008, Memahami Laporan Keuangan, Jakarta: PPM Manajemen.

Darsono, P dan Ari, Purwanti, 2008, Penganggaran Perusahaan, Jakarta: Penerbit Mitra Wancana Media.

Dwi, Martani,2012, Akuntansi Keuangan Menengah Berbasis PSKA, Jakarta: Salemba Empat.

Hansen, Don. R. dan M. Mowen, Mayane. 2007, Manajemen Biasa Akuntansi dan Pengendalian. Buku Dua, Edisi Kesatu, salemba Empat. Jakarta.

Hanafi,2009, Analisis laporan Keuangan. Edisi 4, UUP STIM YKPN, yogyakarta.

Harahap, 2013, Analisis Kritis Atas Laporan Keuangan, Edisi 1, cetakan ke 3, Penerbit: Raja Grafindo Persada, Jakarta.

Horngren,2008, Pengantar akuntansi Manajemen, Jilid 1, Edisi 16, Penerbit Erlangga. 
Kasmir, 2012, Analisis Laporan Keuangan, Edisi pertama, cetakan kesembilan, Jakarta: Penerbit PT. Raja Grafindo Persada.

Mulyadi, 2008, Akuntansi Biaya, Penentuan Harga Pokok dan Pengendalian Biaya, Fakultas Ekonomi (UGM) Yogyakarta.

Nafarin, M, 2007, Penganggaran Perusahaan, Jakarta: Salemba Empat.

Munawir S, 2010, Analisis Laporan Keuangan, Edisi ke 4, Cetakan Kelima Belas, Yogyakarta: Liberty
Prawironegoro, Darsono, 2007, Akuntansi Manajemen, edisi 2, Jakarta: Mira Wacana Media.

Raharjaputra, Hedra, S, 2011, Manajemen Keuangan dan Akuntansi, Jakarta: Salemba Empat.

Rudianto, 2012, Pengantar akuntansi Konsep Dan Tekhnik Penyusunan Laporan Keuangan, Jakarta: Erlangga.

Supriyono, 2014, Akuntansi Biaya Perencanaan dan Pengendalian Biaya Serta Pembuatan Keputusan, Edisi Kedua, Erlangga, Yogyakarta. 